\title{
SIRKULASI TERMINAL PENUMPANG KAPAL LAUT
}

\author{
Etsa Purnama Sari ${ }^{1}$, Emilya Kalsum ${ }^{2}$ \\ ${ }^{1}$ Mahasiswa Program Studi Arsitektur, Fakultas Teknik Universitas Tanjungpura, Indonesia \\ ${ }^{2}$ Dosen Program Studi Arsitektur, Fakultas Teknik Universitas Tanjungpura, Indonesia \\ ie_violet@yahoo.com
}

\begin{abstract}
ABSTRAK
Wilayah Indonesia yang terdiri dari pulau dan perairan menjadikan angkutan laut menjadi salah satu sarana transportasi yang cukup efektif di negara ini. Daya angkut yang besar dan beragam serta biaya yang lebih murah dengan jarak jangkauan yang luas, membuat sarana ini banyak diminati oleh masyarakat sekaligus juga merupakan pendukung utama perkembangan kehidupan sosial budaya dan roda perekonomian. Untuk mendukung proses transportasi laut ini perlu sarana berupa pelabuhan. Pelabuhan dalam melakukan pelayanan terhadap kapal memiliki beberapa fasilitas pokok dan penunjang yang wajib dimiliki. Salah satunya adalah terminal penumpang kapal laut dengan berbagai kegiatan di dalamnya untuk kedatangan maupun keberangkatan. Masalah ketidaknyamanan dalam berkegiatan, jauhnya akses sirkulasi antara satu kegiatan dengan kegiatan kegiatan embarkasi dan debarkasi yang tidak teratur, pembagian jalur sirkulasi penumpang dan pengantar penumpang yang tidak jelas seringkali muncul akibat sirkulasi yang tidak direncanakan dengan baik pada terminal penumpang kapal laut. Bahkan tidak jarang dapat menimbulkan adanya calo tiket hingga adanya penumpang tanpa tiket yang dapat masuk ke dalam kapal hingga kapal berlayar. Perencanaan sebuah sirkulasi yang tepat pada terminal penumpang kapal laut memerlukan kajian terhadap unsur-unsur sirkulasi seperti pencapaian, pola sirkulasi, jalur sirkulasi, serta bentuk ruang sirkulasi. Kajian unsur-unsur ini selanjutnya diselidiki melalui penelusuran masalah dengan analisis deskriptif melalui penggambaran objek penelitian yang terdapat pada Terminal Penumpang Pelabuhan International Yokohama, Terminal Penumpang Pelabuhan Kobe dan Terminal Penumpang Pelabuhan Osanbashi Hall.
\end{abstract}

Kata kunci: Terminal penumpang, sirkulasi

\begin{abstract}
As one of the largest archipelago country, sea transportation acts as one of the most effective means of transportation in Indonesia. Large and diverse carrying capacity, lower cost with wide range of distances, are factors which making sea transportation demand is quite high in public as well as a major proponent of development of social, cultural, and economy. Thus, to support this means of transportation, facility in form of port is needed. port must have some basic and support facilities, which includes ship passenger terminal to accommodate arrival of departure of passengers. Problems which usually occur in ship passenger terminal caused by poor planning of circulation are: discomfort in activities, long distance of circulations which connect one activity to another, disorganized embarkation and disembarkation, and confusing distribution of passengers and passenger's comperes' pathways. From those conditions, sometimes it gives opportunity for ticket brokers and passengers without tickets who could board ships without proper requirements. A proper planning of circulation requires analysis of elements of circulation which includes entrance, circulation pattern, circulation path, and form of circulation space. Furthermore, such elements were studied through problem seeking, then descriptively analyze through research's object depiction from Yokohama International Passenger Terminal, Kobe Port Terminal, and Osanbashi Hall Passenger Terminal.
\end{abstract}

Kata kunci: Passenger terminal, circulation

\section{Pendahuluan}

Secara geografis wilayah Indonesia terdiri dari pulau dan perairan. Keadaan ini menyebabkan Indonesia mendapat julukan negara kepulauan dengan ribuan pulau yang tersebar dan dipisahkan oleh lautan.

Ini menjadikan angkutan laut menjadi salah satu sarana transportasi yang cukup efektif di negara ini karena mendukung jarak pencapaian 
yang relatif jauh dengan kemampuan daya angkut yang besar dan beragam serta biaya yang lebih murah. Karena itu sarana transportasi laut banyak diminati oleh masyarakat dibanding moda angkutan lainnya.

Transportasi laut juga merupakan pendukung utama perkembangan kehidupan sosial budaya dan roda perekonomian saat ini. Ini disebabkan oleh kemampuan transportasi laut dalam menjangkau dan melayani daerah-daerah terpencil di seluruh wilayah Indonesia yang masih sulit dijangkau oleh moda angkutan lain. Untuk mendukung proses transportasi tersebut perlu suatu sarana yang berfungsi sebagai wadah bagi pelaku kegiatan transportasi laut berupa pelabuhan.

Sebagai bagian dari mata rantai transportasi laut, fungsi pelabuhan adalah tempat pertemuan (interface) dua moda angkutan atau lebih serta interface berbagai kepentingan yang saling terkait. Barang yang diangkut dengan kapal akan dibongkar dan dipindahkan ke moda lain seperti moda darat atau udara. Sebaliknya barang yang diangkut dengan moda darat atau udara akan dimuat lagi ke kapal melalui pelabuhan. Oleh sebab itu berbagai kepentingan saling bertemu di pelabuhan seperti perbankan, perusahaan pelayaran, bea cukai, imigrasi, karantina, syahbandar dan pusat kegiatan lainnya. Atas dasar inilah dapat dikatakan bahwa pelabuhan sebagai salah satu infrastruktur transportasi, dapat membangkitkan kegiatan perekonomian suatu wilayah karena merupakan bagian dari mata rantai dari sistem transportasi maupun logistik.

Peran penting dan strategis Pelabuhan adalah untuk menumbuhkan industri dan perdagangan serta merupakan segmen usaha yang dapat memberikan kontribusi bagi pembangunan nasional. Ini membawa konsekuensi terhadap pengelolaan segmen usaha pelabuhan tersebut agar pengoperasiannya dapat dilakukan secara efektif, efisien dan profesional sehingga pelayanan pelabuhan menjadi lancar, aman, dan cepat dengan biaya yang terjangkau. Pelayanan yang diberikan oleh pelabuhan adalah pelayanan terhadap kapal dan pelayanan terhadap muatan (barang dan penumpang).

Pelabuhan dalam melakukan pelayanan terhadap kapal dan muatan (barang dan penumpang) memiliki beberapa fasilitas pokok dan penunjang yang wajib dimiliki. Terminal penumpang kapal laut merupakan salah satu fasilitas pokok yang cukup penting dalam mendukung aktifitas pelayanan penumpang di pelabuhan. Ini disebabkan karena terminal penumpang kapal laut adalah suatu wadah bagi aktifitas proses perpindahan penumpang dari satu sub sistem angkutan ke sub sistem angkutan lain yang berbeda karakteristiknya.

Suatu fasilitas yang mendukung suatu proses perpindahan selayaknya memberi- kan suatu kenyamanan dan kemudahan bagi penggunanya untuk melakukan kegiatan. Kenyamanan dan kemudahan dalam melakukan berbagai kegiatan berhubungan erat dengan sirkulasi antara satu fasilitas dengan fasilitas lainnya. Menurut D.K Ching (2000) sirkulasi merupakan suatu tali yang tak terlihat yang menghubungkan ruang-ruang dalam suatu bangunan, sehingga sirkulasi adalah prasarana penghubung vital yang menghubungkan berbagai kegiatan.

Terminal penumpang kapal laut di Indonesia yang ada pada saat ini masih belum mampu memenuhi kebutuhan pelayanan secara maksimal bagi pengguna jasa transportasi laut akibat sirkulasi penumpang yang tidak jelas dan kurang efisien. Akibatnya, aktivitas dan pergerakan menjadi tidak nyaman, jauhnya akses sirkulasi antara satu kegiatan dengan kegiatan lainnya, kegiatan embarkasi dan debarkasi yang tidak teratur, pembagian jalur sirkulasi penumpang dan pengantar penumpang yang tidak jelas adalah masalah-masalah yang sering muncul akibat sirkulasi yang tidak direncanakan dengan baik. Bahkan tidak jarang dapat menimbulkan adanya calo tiket hingga adanya penumpang tanpa tiket yang dapat masuk ke dalam kapal hingga kapal berlayar.

Pencapaian, pola sirkulasi, jalur sirkulasi, serta bentuk ruang sirkulasi adalah unsur-unsur sirkulasi yang memberi pengaruh terhadap kenyamanan dan kemudahan bagi penggunanya untuk melakukan berbagai kegiatan. Sebuah terminal penumpang kapal laut dengan berbagai aktivitas serta kapasitas manusia dan barang yang tidak sedikit selayaknya mempertimbangkan unsur-unsur tersebut dalam perencanaan sirkulasinya. Sebuah perencanaan yang tepat untuk sebuah sirkulasi pada bangunan terminal penumpang kapal laut bukan saja dapat membuat berbagai kegiatan menjadi lebih mudah dan nyaman. Bahkan dapat membuat fungsi lainnya dari sebuah pelabuhan yaitu pintu gerbang komersial di wilayahnya dapat tercapai.

Untuk merencanakan sebuah sistem sirkulasi yang tepat pada sebuah bangunan terminal penumpang kapal laut diperlukan pengkayaan terhadap pengalaman berbagai potensi dan kendala yang dapat ditimbulkan dalam sebuah desain. Untuk itu sebuah studi kepustakaan yang membahas tentang terminal penumpang kapal laut dan teori tentang sirkulasi perlu dilakukan. Penelusuran masalah yang diselidiki dilakukan melalui metode analisis deskriptif dengan menggambarkan keadaan objek penelitian berdasarkan fakta-fakta yang tampak sebagaimana adanya dengan objek penelitian yang terdapat pada Terminal Penumpang Pelabuhan International Yokohama, Terminal Penumpang Pelabuhan Kobe dan Terminal Penumpang Pelabuhan Osanbashi Hall.

\section{Kajian Pustaka}

\subsection{Terminal Penumpang Kapal Laut}

Pelabuhan adalah tempat yang terdiri dari daratan dan perairan di sekitarnya dengan batas tertentu sebagai tempat kegiatan pemerintahan dan kegiatan ekonomi yang dipergunakan sebagai tempat kapal bersandar, berlabuh, naik dan turun penumpang atau bongkar muat barang yang dilengkapi dengan fasilitas keselamatan pelayaran dan kegiatan penunjang pelabuhan serta sebagai tempat perpindahan intra dan antara moda transportasi (PP RI No. 70 Tahun 1996 tentang Kepelabuhan, Dephub $\mathrm{RI})$. 
Sebagai bagian dari sistem transportasi, pelabuhan memiliki peran penting sebagai titik perubahan moda transportasi, dari darat ke laut, dan sebaliknya; pintu gerbang komersial suatu daerah atau negara; serta tempat penampungan, penyimpanan, dan distribusi barang dan orang (Triatmodjo, 2008). Karena peran inilah, maka pelabuhan harus memiliki berbagai fasilitas. Salah satu dari fasilitas pelabuhan adalah bangunan terminal penumpang.

Terminal Penumpang Kapal Laut adalah komponen utama sub sistem pelabuhan yang berfungsi mewadahi aktifitas proses perpindahan penumpang dari satu sistem angkutan laut (kapal penumpang) ke sarana angkutan lain atau sebaliknya (Marlok, 1991; Haronjeff, 1993; Andiani, 2011).

Akibat fungsinya sebagai wadah aktifitas proses perpindahan penumpang, menjadikan terminal penumpang memiliki banyak fasilitas dengan tingkat kebutuhan sirkulasi yang cukup tinggi. Aktifitas yang terjadi di dalam terminal terutama dipengaruhi oleh manusia dan barang yang meliputi (Andiani, 2011):

- Penumpang

Penumpang dibagi dalam penumpang domestik dan turis yang melakukan kegiatan embarkasi yaitu berangkat dari terminal penumpang dan debarkasi yaitu kedatangan atau menuju ke terminal penumpang.

- Pengantar dan penjemput

- Pengelola terminal meliputi:

$\checkmark$ Karyawan terminal, yaitu yang bertanggung jawab langsung tentang keadaan terminal baik operasional maupun administrasi.

$\checkmark$ Karyawan perusahaan pelayanan, yaitu yang melakukan kegiatan operasional di dalam terminal penumpang, yaitu penjualan karcis dan pembagasian.

$\checkmark$ Karyawan dari pemerintah, yaitu dalam divisi kesehatan, bea cukai, hukum (imigrasi dan emigrasi).

- Barang bawaan meliputi:

$\checkmark$ Barang yang biasa dibawa

$\checkmark$ Barang over bagasi

$\checkmark$ Barang muatan bukan kargo, yaitu barang bawaan yang langsung dimasukkan bagasi, seperti barang pindahan, barang elektronik berukuran besar, dan barang dagangan jumlah banyak.

Sementara fasilitas yang terdapat di terminal penumpang secara pokok dapat dibagi menjadi dua kelompok besar, yaitu (Andiani, 2011):

1. Fasilitas pelayanan dan penumpang kapal

- Daerah kedatangan atau keberangkatan untuk menaikkan atau menurunkan penumpang.

- Fasilitas parkir untuk mobil, sepeda motor (roda 2), dan pejalan kaki.

- Fasilitas untuk menaikkan dan menurunkan penumpang, misal halte dan taxi area

- Loket penjualan tiket dan cek bagasi

- Loket kesehatan (karantina)
- Loket persyaratan hukum (emigrasi dan imigrasi)

- Fasilitas pengambilan bagasi

- Ruang untuk pergerakan penumpang

- Ruang tunggu dan istirahat

- Fasilitas penunjang pelayanan, seperti telepon umum dan restoran.

- Fasilitas informasi jadwal dan rute perjalanan

- Fasilitas untuk pengantar dan penjemput

- Fasilitas penumpang keberangkatan seperti fasilitas penghubung (mobil, ban berjalan).

2. Fasilitas pengelola terminal

- Kantor untuk personil pengelola

- Kantor untuk personil imigrasi dan bea cukai

- Kantor untuk personil kesehatan dan karantina

- Kantor untuk personil keamanan.

Selanjutnya sistem perpindahan penumpang dan barang dapat diuraikan sebagai berikut (Andiani, 2011):

- Sistem perpindahan penumpang

$\checkmark$ Berjalan kaki, bila jarak kapal dengan terminal dekat.

$\checkmark$ Dengan kendaraan darat, bila jarak kapal dengan terminal jauh.

$\checkmark$ Dengan jembatan, untuk efisiensi karena dapat menggunakan area bawah dengan atas secara bersamaan

- $\quad$ Sistem perpindahan bagasi

$\checkmark$ Cart, bagasi diangkut dengan kereta dan kemudian dipindahkan dengan tangan ke lokasi pengambilan.

$\checkmark$ Conveyor, perpindahan bagasi dengan ban berjalan.

Adanya pergerakan yang besar dari penumpang dan barang yang terdapat dalam terminal penumpang ini menuntut sebuah pemikiran yang matang terhadap desain sirkulasi sebuah bangunan terminal penumpang. Ini diperlukan agar berbagai kegiatan dapat berjalan lancar secara efektif dan efisien tanpa adanya kebingungan maupun crossing antar kegiatan. Sebuah desain sirkulasi bangunan terminal penumpang yang baik, bahkan dapat menjadikan fungsi pelabuhan sebagai gerbang kawasan menjadi lebih optimal.

\subsection{Sirkulasi}

Sirkulasi adalah suatu pola lalu lintas atau pergerakan yang ada dalam suatu area atau bangunan yang memberikan keluwesan, pertimbangan ekonomis dan fungsional (Cryill,1975). Faktor-faktor yang mempengaruhi keberhasilan desain sebuah sirkulasi adalah pencapaian, pintu masuk, pola sirkulasi, jalur sirkulasi, bentuk ruang sirkulasi (Ching, 2000).

\section{Pencapaian Ke Bangunan}

Pencapaian ke bangunan adalah suatu proses perjalanan (pendekatan) menuju suatu bangunan melalui akses jalan yang disediakan atau sudah ada (Ching, 2000). Dalam pencapaian ke suatu bangunan dibagi menjadi 
tiga yaitu pencapaian langsung, pencapaian tersamarkan dan pencapaian berputar

\section{Pencapaian Langsung}

Pencapaian langsung adalah pendekat- an yang mengarah langsung ke suatu tempat masuk, melalui sebuah jalan lurus segaris dengan alur sumbu bangunan. Tujuan visual yang mengakhiri pencapaian ini jelas, dapat merupakan fasade muka seluruhnya dari sebuah bangunan atau suatu perluasan tempat masuk di dalam bidang.

\section{Pencapaian Tersamarkan}

Pencapaian tersamarkan adalah pendekatan yang samar-samar meningkat- kan efek perspektif pada fasade depan dan bentuk suatu bangunan. Jalur dapat dirubah arahnya satu atau beberapa kali untuk menghambat dan memperpanjang urutan pencapaian.

Fasad bangunan tidak menampakkan perspektif bangunan. Pecapaian secara tegak lurus juga tidak tercapai. Ini disebabkan karena

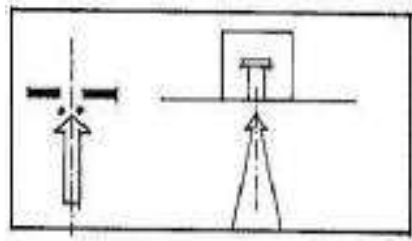

(a)

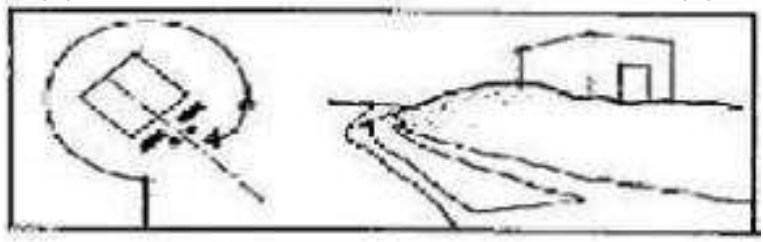

(c)

Gambar 1 : Berbagai bentuk pencapaian ke bangunan: (a) pencapaian langsung, (b) pencapaian tersamarkan, (c) pencapaian berputar Sumber : Ching (2000)

\section{Pintu Masuk}

Menurut Ching (2000), Pintu merupakan jalan masuk yang paling utama ke dalam bangunan yang menghubungkan ruang luar dan dalam bangunan. ada tiga macam pintu dalam bangunan yaitu:

- Pintu masuk yang rata mempertahankan kontinuitas permukaan dinding dan jika diinginkan dapat sengaja dibuat tersamar.

- Pintu masuk yang menjorok ke luar membentuk sebuah ruang transisi, menunjukkan fungsinya sebagai pendekatan dan memberikan perlindungan di atasnya.

- Pintu masuk yang menjorok ke dalam juga memberikan perlindungan dan menerima sebagian ruang eksterior menjadi bagian dalam bangunan.

\section{Pola-pola Sirkulasi}

Menurut Ching (2000), pola sirkulasi diperlukan untuk memaksimalkan pergerakan dari suatu ruang ke ruang lainnya. Pola sirkulasi juga dapat dimaksudkan untuk menambah estetika bangunan atau ruang. Pola sirkulasi pintu masuk ke bangunan berada di sisi jalan sehingga apabila seseorang melintasi jalan tersebut visualisasinya tidak akan ke bangunan melainkan tegak lurus ke arah jalan. Maka bangunan tersebut merupakan bangunan yang pencapaiannya tersamar.

\section{Pencapaian Berputar}

Pencapaian berputar adalah jalan berputar yang memperpanjang urutan pencapaian dan mempertegas bentuk tiga dimensi suatu bangunan dan bergerak mengelilingi tipe bangunan. Jalan masuk bangunan mungkin dapat dilihat terputus- putus selama waktu pendekatan untuk memperjelas posisinya atau dapat tersembunyi sampai di tempat kedatangan.

Pencapaian bangunan dapat dilakukan secara memutar untuk memasuki bangunan tersebut karena pintu masuk yang tersamar dan berputar di segala sisi.

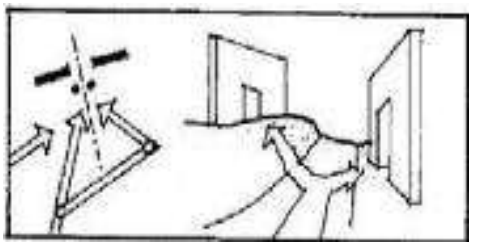

(b) ruang dibagi menjadi pola linier, pola radial, pola spiral, pola network dan pola campuran.

\section{Pola Linier}

Suatu pola sirkulasi berupa garis yang mempunyai arah sehingga dapat menjadi unsur pembentuk deretan ruang. Pola ini sangat sering ditemui karena banyak dipergunakan. Contoh : jalan raya, jalan tol, sirkuit, lorong sekolah dan rumah sakit, dan lain-lain.

\section{Pola Radial}

Suatu pola sirkulasi melalui penyebaran atau perkembangan dari titik pusat. Biasanya pola radial ini terdapat banyak ruang pergerakan. Karena pola yang digunakan sama seperti pola yang digunakan pada jari-jari sepeda. Contoh : gym, stadium, dan sebagainya.

\section{Pola Spiral}

Suatu pola sirkulasi ruang dengan cara berputar menjauhi titik pusat. Pola sirkulasi ini efektif pada lahan yang mempunyai luas terbatas dan pada lahan yang mempunyai kontur tanah yang curam. Contoh : ram parkiran di mal, jalan di daerah pegunungan, dan sebagainya. 
Pola Network

Suatu pola sirkulasi berupa jaringan (penyatuan) dari beberapa ruang gerak untuk menghubungkan titik-titik berpadu dalam suatu ruang. Umumnya pola ini dipergunakan pada ruang-ruang gedung perkantoran yang dimaksudkan agar setiap orang bisa dengan mudah beraktivitas.

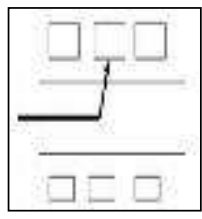

(a)

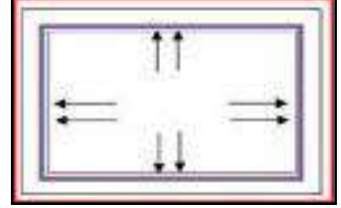

(b)

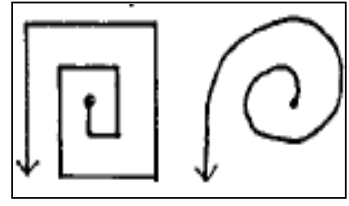

(c)

\section{Pola Campuran}

Suatu pola sirkulasi yang terdiri dari gabungan empat pola (linier, radial, spiral dan network) untuk menciptakan suatu pola yang berbeda yang menimbulkan kesan harmonisasi dari perpaduan empat pola. Akan tetapi untuk menciptakannya amat sulit. Apabila tidak sesuai akan menimbul- kan kesan membingungkan.

Gambar 2 : Berbagai bentuk pola sirkulasi: (a) pola linier, (b) pola radial, (c) pola spiral, (d) pola network, (e) pola campuran Sumber : Ching (2000)

\section{Jalur Sirkulasi}

Menurut Ching (2000), jalur sirkulasi adalah pergerakan atau ruang lingkup gerak suatu ruang yang saling berhubungan baik dengan fungsi, bentuk dan lain-lain. Jalur sirkulasi penghubung ruang dibagi menjadi 3 , yaitu melewati ruang, menembus ruang dan berakhir dalam ruang.

\section{Jalur Sirkulasi Melewati Ruang}

Jalur sirkulasi melewati ruang adalah suatu pergerakan atau ruang lingkup gerak yang berfungsi sebagai penghubung ruang satu dengan lainnya. Jalur sirkulasi melewati ruang ini memiliki beberapa ciri:

- Mempertahankan integritas ruang (keutuhan ruang, tanpa mengganggu ruang lainnya)

- Menunjukkan ruang yang bebas (jalan, lorong, dan sebagainya)

- Menghubungkan ruang satu dengan lainnya

- Mempertahankan kesatuan dari ruangan-ruangan yang ada dengan konfigurasi jalan yang fleksibel.

Jalur Sirkulasi Menembus Ruang

Sirkulasi menembus ruang adalah suatu pergerakan atau/ruang lingkup gerak yang berfungsi sebagai penghubung ruang satu dengan lainnya melalui atau menembus ruang yang lain. Jalur sirkulasi menembus ruang memiliki beberapa ciri:

- Sirkulasi menembus sebuah ruang dapat menerus sumbunya, miring, atau sepanjang sisinya.

- Sirkulasi dapat membentuk pola wilayah-wilayah tertentu untuk aktivitas dan gerak dalam ruang tersebut.

Jalur Sirkulasi Berakhir Dalam ruang

Sirkulasi yang berakhir di dalam ruang adalah suatu pergerakan atau ruang lingkup gerak yang berfungsi sebagai pemberi fokus akses penghubung ruang yang dianggap penting dan berakhir pada satu ruang. Jalur sirkulasi berakhir dalam ruang ini memiliki beberapa ciri:
- Lokasi ruangan menghasilkan jalur sirkulasi.

- Biasanya sirkulasi berakhir pada ruangan pertemuan.

- Berkesan fungsional dan formal

- Biasanya mempunyai satu akses jalan

\section{Bentuk Ruang Sirkulasi}

Menurut Ching (2000), Bentuk ruang sirkulasi dapat dibedakan menjadi bentuk tertutup, terbuka pada salah satu sisi dan terbuka pada kedua sisi.

\section{Ruang Sirkulasi Tertutup}

Ruang sirkulasi tertutup membentuk galeri umum atau koridor pribadi yang berkaitan dengan ruang-ruang yang dihubungkan melalui pintu-pintu masuk pada bidang dinding.

\section{Ruang Sirkulasi Terbuka pada Salah Satu Sisinya}

Ruang sirkulasi terbuka pada salah satu sisinya membentuk balkon atau galeri yang memberikan kontinuitas visual dan kontinuitas ruang dengan ruang-ruang yang dihubungkannya.

\section{Ruang Sirkulasi Terbuka pada Kedua Sisinya}

Ruang sirkulasi terbuka pada kedua sisinya membentuk deretan kolom untuk jalan lintas yang menjadi sebuah perluasan fisik dari ruang yang ditembusnya.

\section{Pembahasan}

Pembahasan mengenai sirkulasi terminal penumpang kapal laut ini akan mengacu pada 3 (tiga) buah bangunan yaitu Terminal Penumpang Internasional Yoko- hama, Terminal Penumpang Osanbashi Hall dan Terminal Penumpang Internasional Kobe.

Terminal Penumpang Pelabuhan Internasional Yokohama terletak di sebelah ujung Barat Laut dari Tokyo Bay. Saat ini Terminal penumpang internasional Yokohama dikenal sebagai pintu gerbang Jepang melalui jalur laut. Terminal penumpang pelabuhan internasional Yokohama ini dapat menampung hingga empat kapal kelas 30.000 ton atau dua kapal kelas 
70.000 ton. Area keberangkatan/kedatangan, lobby, ticket booth, bea cukai, imigrasi, toko-toko dan kafe berada di lantai 2 . Lantai 1 terdapat area parkir dan terdapat dek observasi terbuka untuk umum di atap. Terminal ini dibuka untuk 24 jam sehari.

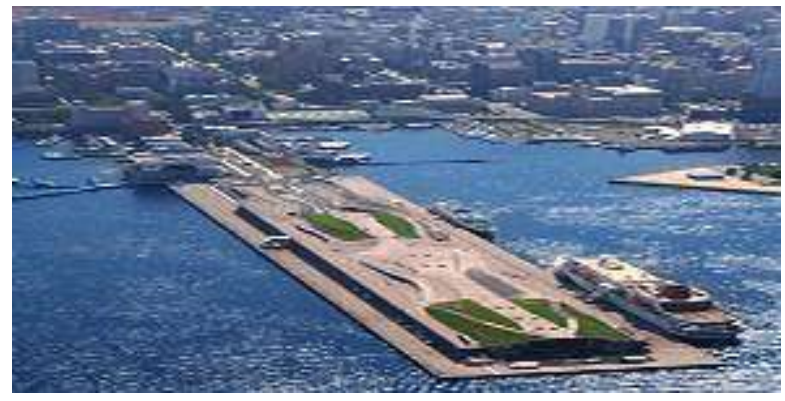

Gambar 3 : Terminal penumpang Pelabuhan Internasional Yokohama tampak dari udara Sumber : www.osanbashi.com, diunduh 14 Juni 2013

Terminal Penumpang Osanbashi Hall memiliki lobby yang multi fungsi terletak di ujung lantai 2. Pengunjung terminal sebagian besar memilih untuk bersantai di lobby setelah menikmati pemandangan teluk. sekitar pelabuhan atau kapal pesiar datang dan pergi melalui dinding-dinding kaca. Dengan langit-langit tinggi $6 \mathrm{~m}$ sampai $8 \mathrm{~m}$ dan area seluas $2.000 \mathrm{~m}^{2}$. Lobby Osanbashi Hall dapat menjadi tempat untuk berbagai acara, seperti kuliah pertemuan, pameran, pesta, dan pernikahan. Ada juga sebuah restoran di sisi Shinko (menghadap Red Brick Warehouse).

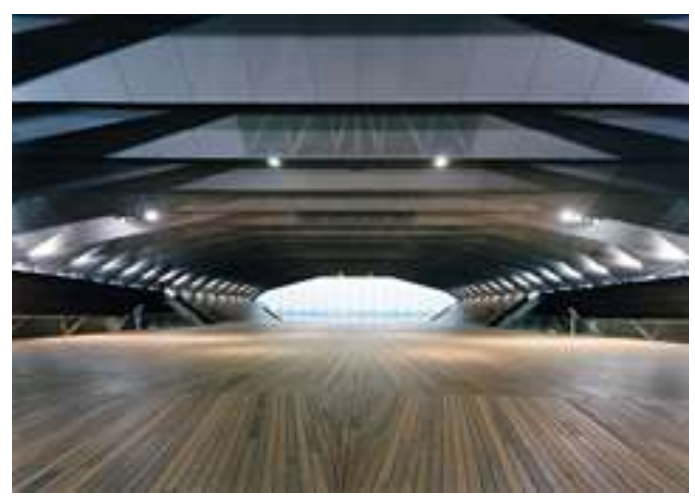

Gambar 4 : Osanbashi Hall

Sumber : www.osanbashi.com, diunduh 14 Juni 2013

Terminal Penumpang Internasional Kobe didirikan sebagai salah satu pelabuhan perputaran di Asia karena memiliki terminal fungsional, yang dapat menangani skala besar untuk lebih dari 4.000 penumpang. Selain itu, Pelabuhan Kobe memiliki akses yang baik ke Bandara Internasional Kansai Airport (KIX) dan
Kobe domestik. Salah satu keuntungan dari pelabuhan Kobe adalah kedekatannya ke pusat kota. Selain itu, ada berbagai sarana transportasi, pelabuhan kapal, kereta bawah tanah, kereta api dan jalan layang dengan akses untuk berbelanja dan tamasya.

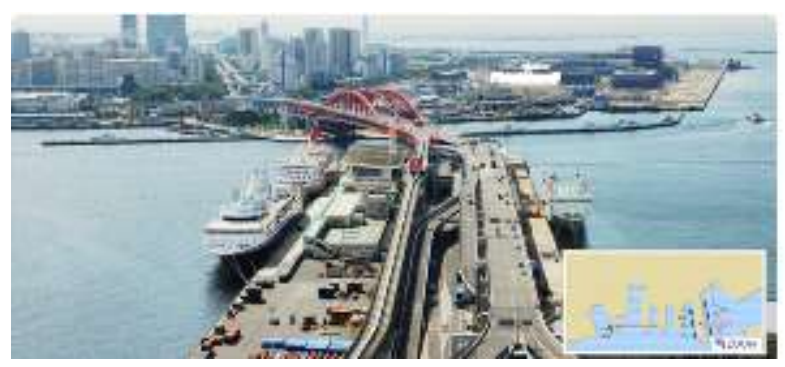

Gambar 5 : Terminal pelabuhan kobe tampak dari udara Sumber : www.kobe-meriken.or.jp, diunduh 16 Juni 2013

\subsection{Pencapaian ke Bangunan}

Ketiga terminal penumpang menggunakan pencapaian langsung ke bangunan. Bahkan pada Terminal Penumpang Internasional Kobe pencapaian langsung ini terdapat pada semua akses masuk yang berasal dari jalur transportasi dengan moda lainnya. Sehingga ketika seseorang sampai dan turun dari kendaraan, 
mereka tak lagi bingung menemukan terminal karena sudah sampai di dalamnya.
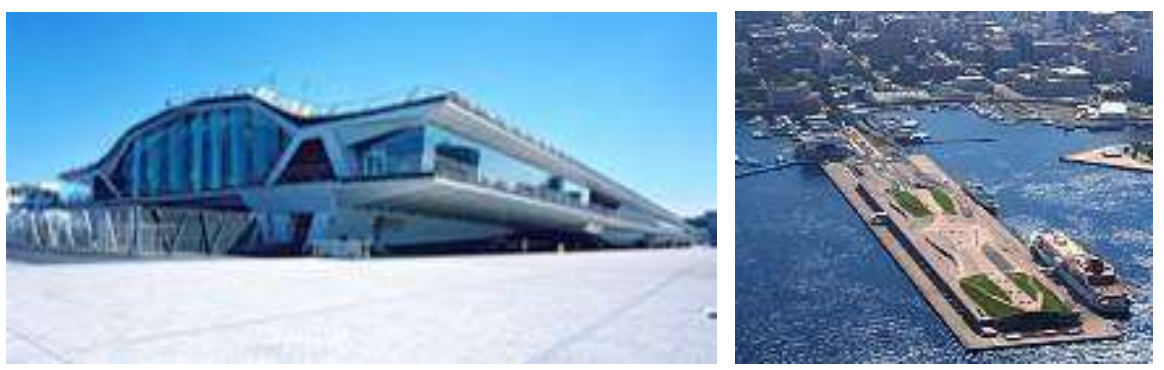

Gambar 6 : Pencapaian secara langsung Terminal Penumpang Pelabuhan Internasional Yokohama Sumber : www.osanbashi.com, diunduh 14 Juni 2013

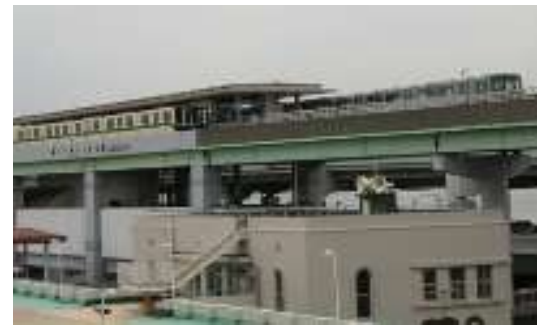

Gambar 7 : Terminal Pelabuhan Kobe tampak dari arah laut dapat terlihat banyak akses jalan untuk menuju ke bangunan

Sumber : www.kobe-meriken.or.jp, diunduh 16 Juni 2013

\subsection{Pintu Masuk}

Meskipun kedua terminal penumpang memiliki pencapaian langsung, namun keduanya juga memiliki pintu masuk yang menjorok ke dalam. Ini dapat dilakukan karena dengan pencapaian langsung, pintu masuk yang menjorok ke dalam tidak akan membingungkan

justru akan mempertegas jalur masuk. Keuntungan lain yang dapat diperoleh dari pintu masuk seperti ini adalah menerima sebagian ruang eksterior menjadi bagian dalam bangunan. Sebagai bangunan publik, pintu masuk seperti ini akan mempertegas kesan menerima dari bangunan ini.

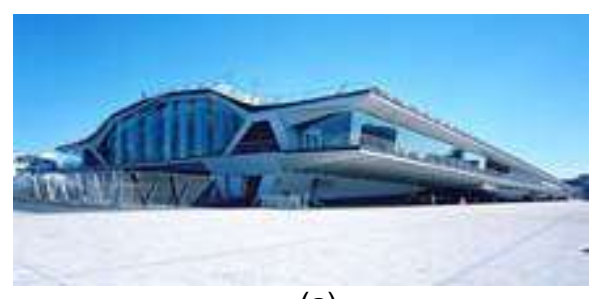

(a)

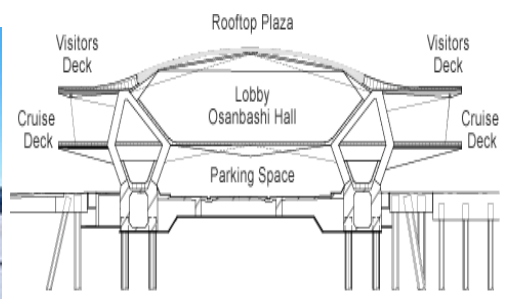

(b)

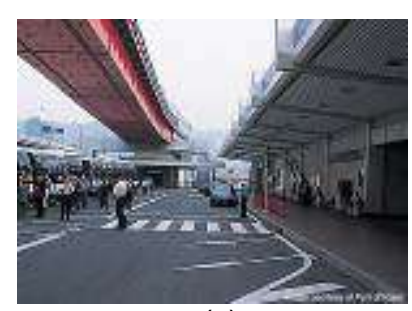

(c)

Gambar 8 : Pintu masuk penumpang pada Pelabuhan Internasional Yokohama (a dan b) dan Terminal Penumpang Pelabuhan Kobe (c)

Sumber : www.osanbashi.com, diunduh 14 Juni 2013 (a, b); www.kobe-meriken.or.jp, diunduh 16 Juni 2013 (c)

\subsection{Pola Sirkulasi}

Terdapat 2 (dua) pola sirkulasi yang terdapat pada ketiga bangunan terminal penumpang yaitu pola linier dan pola radial. Pada Terminal Penumpang Pelabuhan Internasional Yokohama, pola linier ini terdapat pada jalur masuk, dan lobby. Pada jalur masuk pola linier dimaksudkan untuk memperjelas arah yang dituju oleh pengunjung dari area parkir yaitu lobby lantai 1 . Sedangkan pola linier pada lobby untuk membuat pengunjung merasakan arah pergerakan sehingga pengunjung dapat merasakan pergerakan dari meja informasi dan check-in counter yang menangani prosedur keberangkatan dan jasa pengiriman bagasi menuju ke kafe dan tujuh toko yang juga terdapat di lobby seluas $4.400 \mathrm{~m}^{2}$ tersebut. 

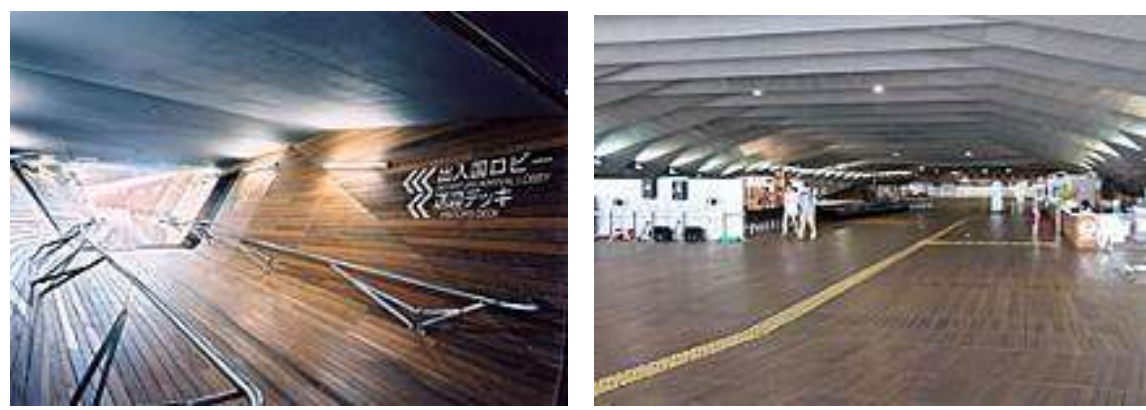

Gambar 9 : Ramp yang bisa digunakan sebagai sirkulasi utama untuk menuju tiap lantai terminal pada Pelabuhan Internasional Yokohama (kiri) dan lobby terminal (kanan) Sumber : www.osanbashi.com, diunduh 14 Juni 2013

Pola linier pada Terminal Penumpang Osanbashi Hall terdapat pada lobby dan anjungan. Pada lobby yang luasnya kira-kira $3000 \mathrm{~m}^{2}$.terdapat fasilitas CIQ (Bea Cukai, Imigrasi dan karantina). Pola sirkulasi yang digunakan pada area ini mengharuskan para penumpang untuk mengantri dalam melakukan kegiatan pengurusan bea cukai, imigrasi, dan karantina.
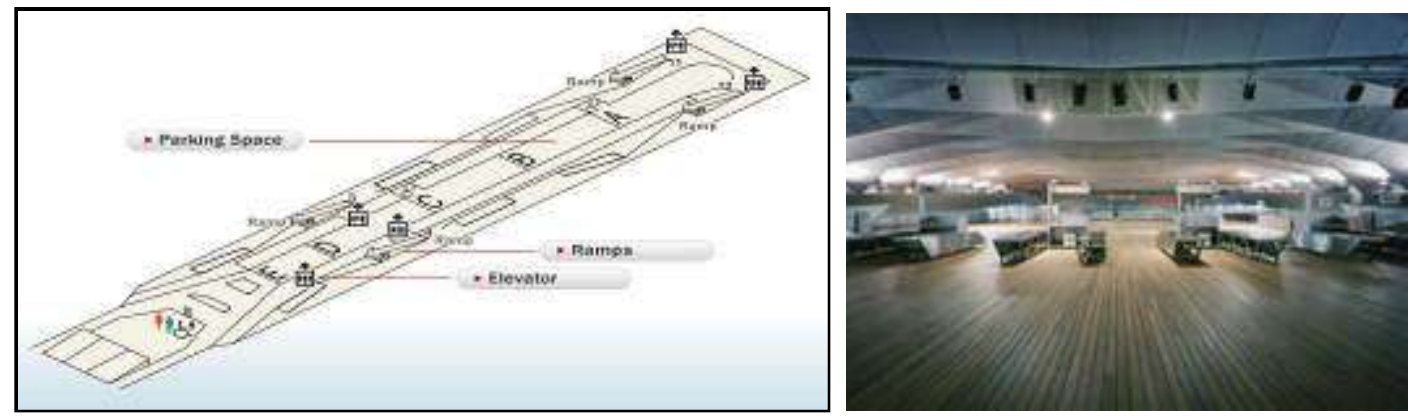

Gambar 10 : Denah lantai 1 (kiri) dan Fasilitas CIQ (Bea cukai, imigrasi dan karantina) (kanan) pada Terminal Penumpang Osanbashi Hall

Sumber : www.osanbashi.com, diunduh 14 Juni 2013

Selain fasilitas $\mathrm{CIQ}$, lobby Terminal penumpang Osanbashi Hall juga memiliki tujuh toko suvenir, kafe dengan pemandangan laut, dan sebuah restoran yang penuh dengan pemandangan panorama pelabuhan di akhir terminal. Pola linier membuat seluruh toko dan restoran tersusun berjejer. Pola ini memungkinkan para pengunjung untuk lebih mudah melihat dan memilih toko mana yang akan mereka kunjungi.

Pola linier yang terdapat pada anjungan berbentuk plaza pada bagian atap dibagi menjadi dua area untuk pejalan kaki. Pola ini memberikan arah bagi pengunjung untuk berjalan di sepanjang plaza. Dengan demikian penumpang on board dapat Ini menikmati pemandangan tanpa terhalang pelabuhan dan kota. Sebaliknya pengunjung lainnya dapat menyambut kapal-kapal pesiar tiba atau melihat penumpang yang berangkat. Anjungan yang dilengkapi dengan dek kayu dan rumput alam ini juga dibuka untuk umum selama 24 jam sehari.

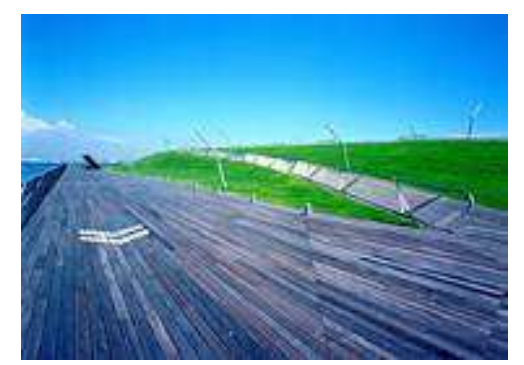

Gambar 11 : Toko-toko dan restoran (kiri) dan dek penumpang (kanan) pada Terminal Penumpang Osanbashi Hall

Sumber : www.osanbashi.com, diunduh 14 Juni 2013

Pada Terminal Penumpang Internasional Kobe, pola linier terdapat pada lobby, CIQ keberangkatan dan $\mathrm{CIQ}$ Kedatangan, boarding bridge, pusat informasi turis, money exchange dan kantor. 


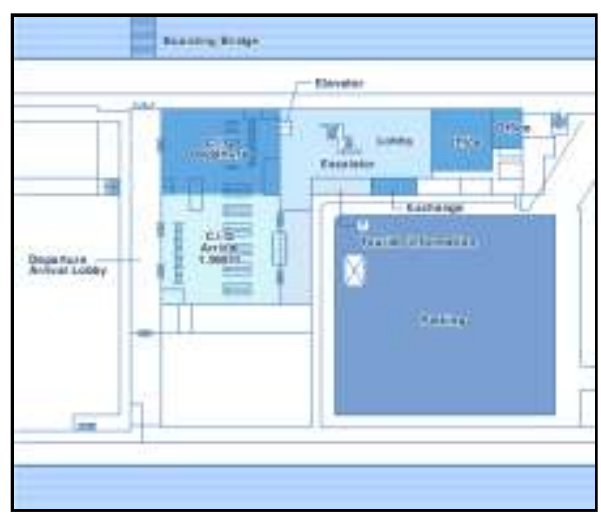

Gambar 12 : Denah lantai 2 Terminal Penumpang Internasional Kobe Sumber : www.kobe-meriken.or.jp, diunduh 16 Juni 2013

Pola linier yang terdapat pada lobby dimaksudkan untuk mengarahkan pengunjung pada satu pintu. Sedangkan pola linier untuk ruang-ruang lainnya dimaksudkan agar pengunjung harus mengantri pada bagian tersebut sehingga kegiatan yang terjadi di dalam
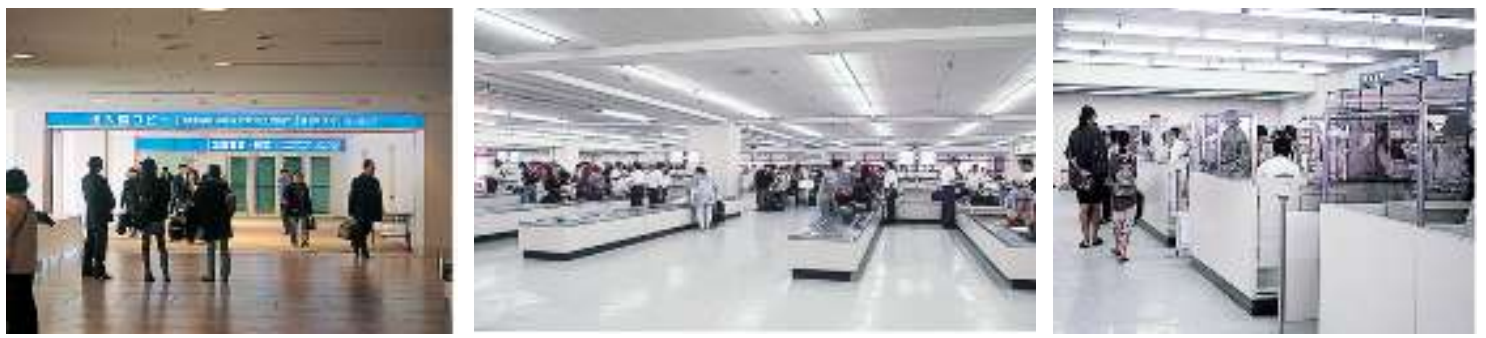

Gambar 13 : Lobby Keberangkatan (kiri), area pengurusan bea cukai (tengah), dan area pengurusan imigrasi (kanan) pada Terminal Penumpang Internasional Kobe Sumber : www.kobe-meriken.or.jp, diunduh 16 Juni 2013
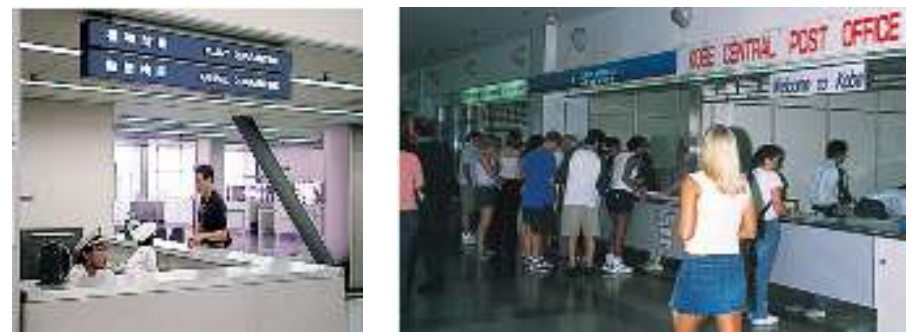

Gambar 14 : Area pengurusan karantina (kiri) dan pusat informasi turis dan money exchange (kanan) pada Terminal Penumpang Internasional Kobe

Sumber : www.kobe-meriken.or.jp, diunduh 16 Juni 2013

Sementara itu pola radial pada Terminal Penumpang Pelabuhan Internasional Yokohama terdapat pada area parkir. Pola ini membuat pengunjung bebas menuju kemana saja arah yang mereka inginkan untuk melakukan tur di sekitar Kota Yokohama. Karena itu, area parkir ini juga digunakan bukan oleh pengunjung terminal.

Sementara pola radial pada Terminal Penumpang Osanbashi Hall terdapat pada lounge dan plaza lantai atap. Ruang dekat pintu masuk ke Osanbashi Hall dapat digunakan sebagai panggung untuk acara seperti mini-konser dan pertunjukan tari dengan ramp sekitarnya yang berfungsi sebagai kursi penonton. Pola radial dimaksudkan agar pengunjung dapat dengan mudah mencapai kedua area ini dan sebaliknya juga mudah bergerak menuju fasilitas yang satu ke fasilitas lainnya. 


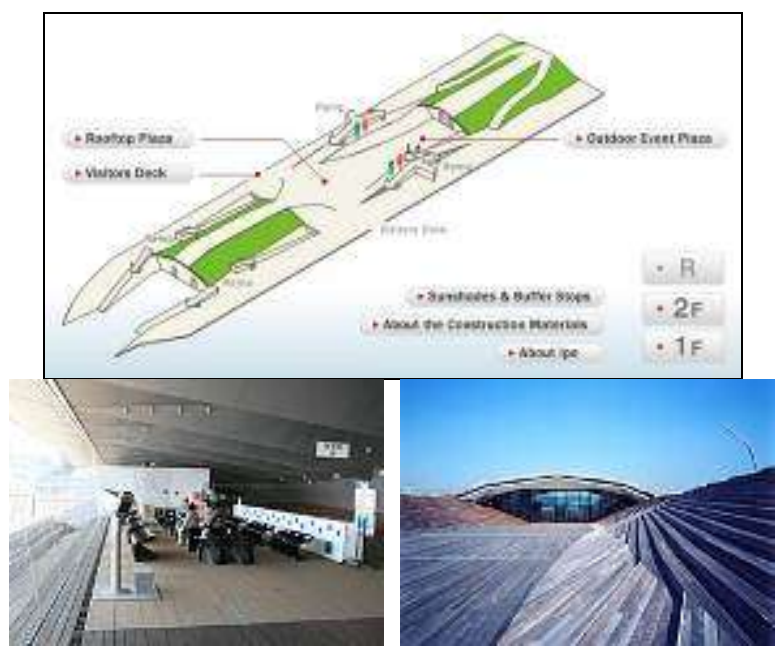

Gambar 15 : Denah lantai atap (atas) dan suasana pada lounge (kiri bawah) dan plaza lantai atap (kanan bawah) pada Terminal Penumpang Osanbashi Hall

Sumber : www.osanbashi.com, diunduh 14 Juni 2013

Pola radial yang terdapat pada Terminal Penumpang Kobe terdapat pada lobby semua lantai. Ini memudahkan pengunjung untuk

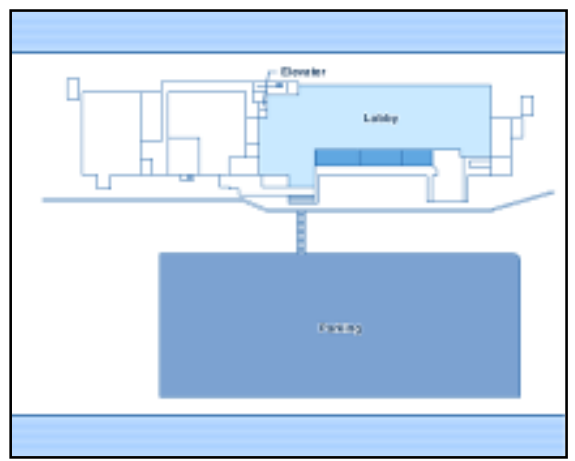

melakukan aktifitas tanpa harus memutar atau melalui ruangan tertentu.

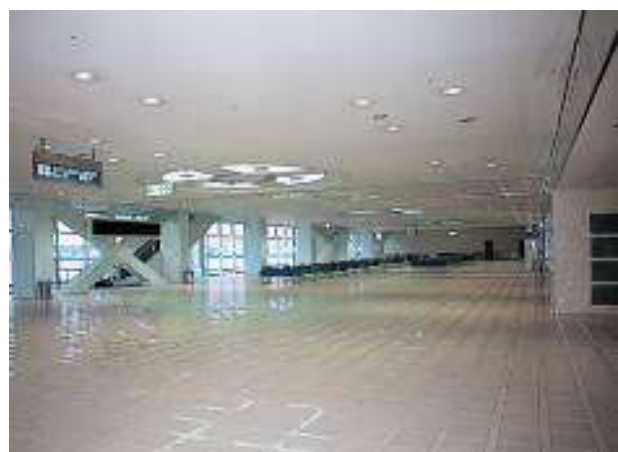

Gambar 16 : Denah lantai 1 (kiri) dan suasana lobby lantai 1 (kanan) pada Terminal Penumpang Kobe Sumber : www.kobe-meriken.or.jp, diunduh 16 Juni 2013

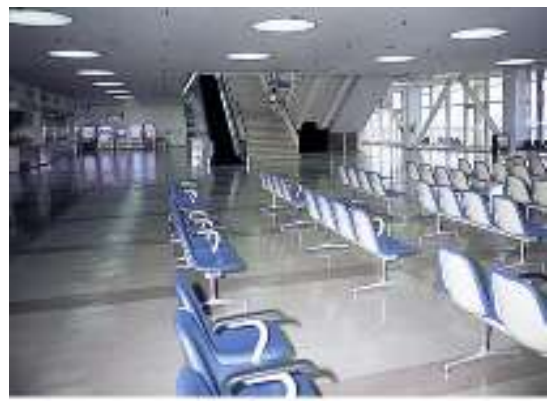

Gambar 17 : Suasana lobby lantai 2 Terminal Penumpang Kobe Sumber : www.kobe-meriken.or.jp, diunduh 16 Juni 2013
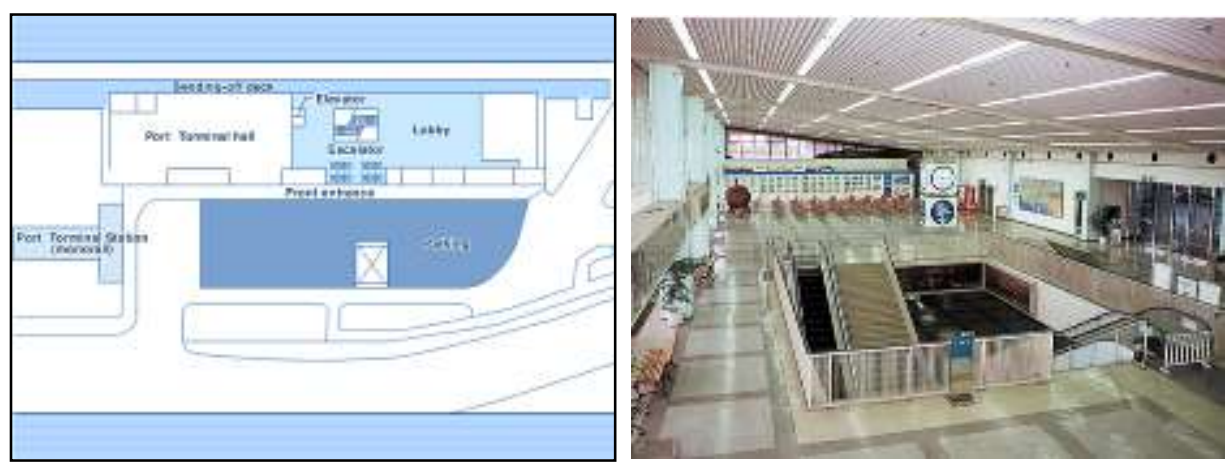
Gambar 18 : Denah lantai 3 (kiri) dan suasana lobby lantai 3 (kanan) Terminal Penumpang Kobe Sumber : www.kobe-meriken.or.jp, diunduh 16 Juni 2013

\subsection{Jalur Sirkulasi}

Bentuk jalur sirkulasi yang terdapat pada ketiga bangunan terdiri dari jalur sirkulasi berakhir pada ruang, menembus ruang dan melewati ruang. Jalur sirkulasi berakhir pada ruang terdapat pada ruang-ruang lantai 1 di
Terminal Penumpang Osanbashi Hall yang berakhir pada ruang parkir dan pada ruang-ruang lantai Terminal Penumpang Internasional Kobe yang berakhir pada lobby. Jalur sirkulasi ini dimaksudkan untuk mengarahkan.
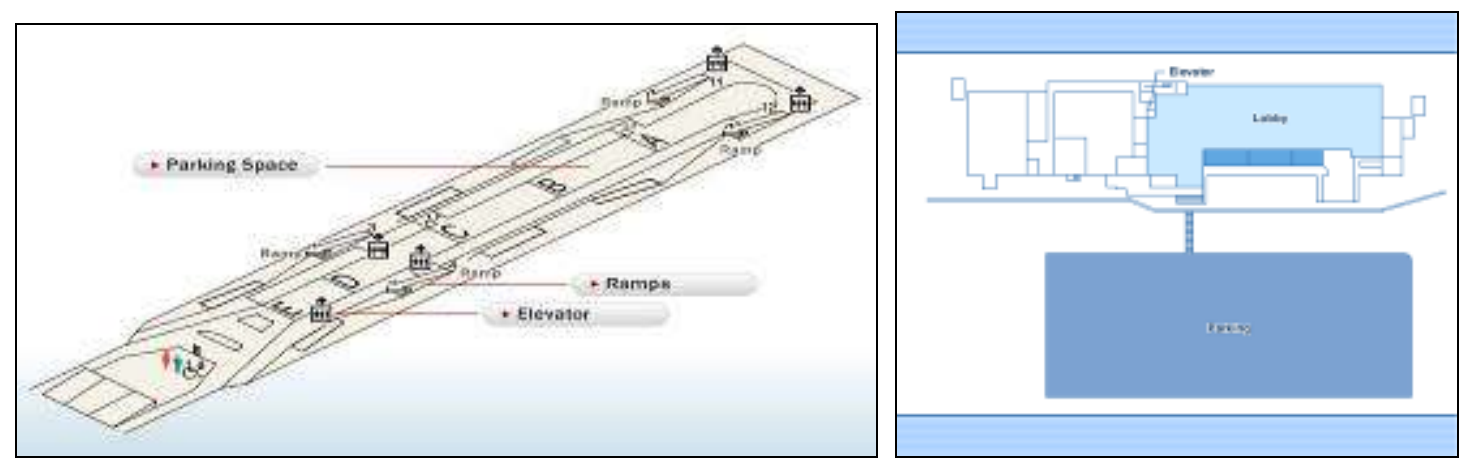

Gambar 19 : Denah lantai 1 Terminal Penumpang Osanbashi Hall (kiri) dan Terminal Penumpang Internasional Kobe (kanan)

Sumber : www.osanbashi.com, diunduh 14 Juni 2013 dan www.kobe-meriken.or.jp, diunduh 16 Juni 2013

Jalur sirkulasi menembus ruang terdapat pada ruang-ruang di lantai 2 dan lantai atap pada Terminal Penumpang Osanbashi Hall. Ini membuat pengunjung terpaksa melewati ruang-ruang komersial. Dengan demikian ruang komersial akan selalu ramai oleh pengunjung. Bentuk jalur sirkulasi yang sama juga terdapat pada ruang-ruang di lantai 2 pada Terminal penumpang Internasional Kobe.
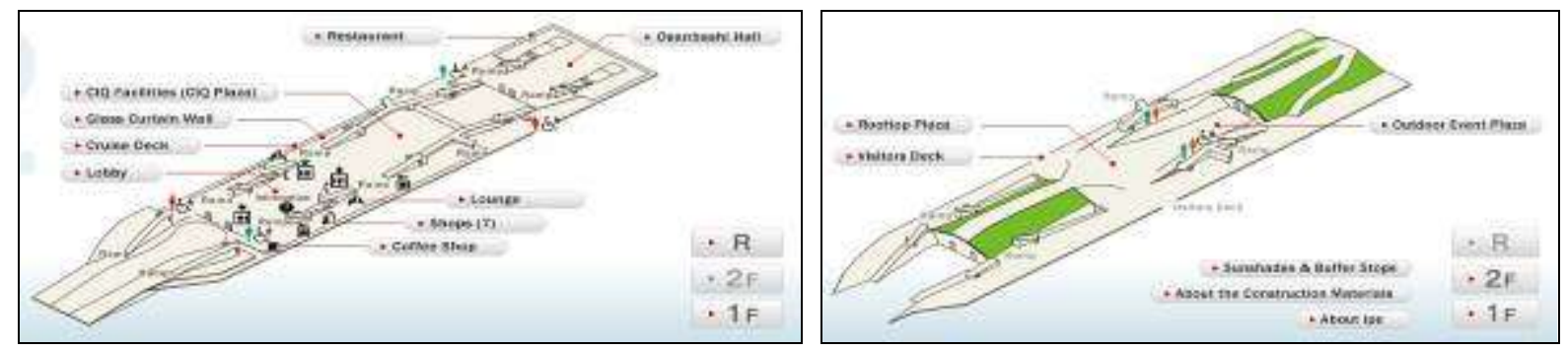

Gambar 20 : Denah lantai 2 (kiri) dan denah lantai atap (kanan) Terminal Penumpang Osanbashi Hall Sumber : www.osanbashi.com, diunduh 14 Juni 2013
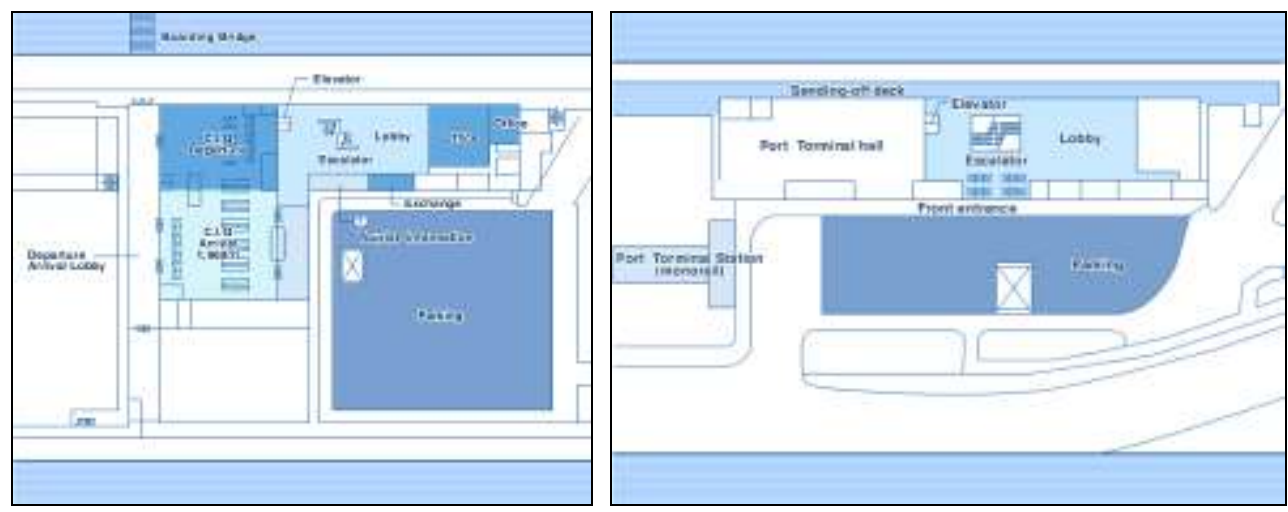

Gambar 21 : Denah lantai 2 (kiri) dan lantai 3 (kanan) Terminal Penumpang Internasional Kobe Sumber : www.kobe-meriken.or.jp, diunduh 16 Juni 2013

Sementara itu, bentuk jalur sirkulasi yang melewati ruang terdapat di ruang-ruang lantai 3 pada Terminal Penumpang Internasional Kobe.
Jalur sirkulasi seperti ini membuat pengunjung merasa mudah untuk mendatangi ruang-ruang 
yang dituju tanpa terganggu dengan aktivitas di jalur sirkulasi tersebut (Gambar 21).

\subsection{Bentuk Ruang Sirkulasi}

Ruang sirkulasi pada ketiga bangunan menggunakan bentuk terbuka kedua sisi, terbuka di satu sisi dan tertutup. Bentuk ruang sirkulasi yang terbuka kedua sisi terdapat pada sirkulasi parkir dan lobby pada Terminal Penumpang Osanbashi Hall. Ini membuat peran area parkir dan lobby sebagai penghubung antara klain menjadi lebih tegas.
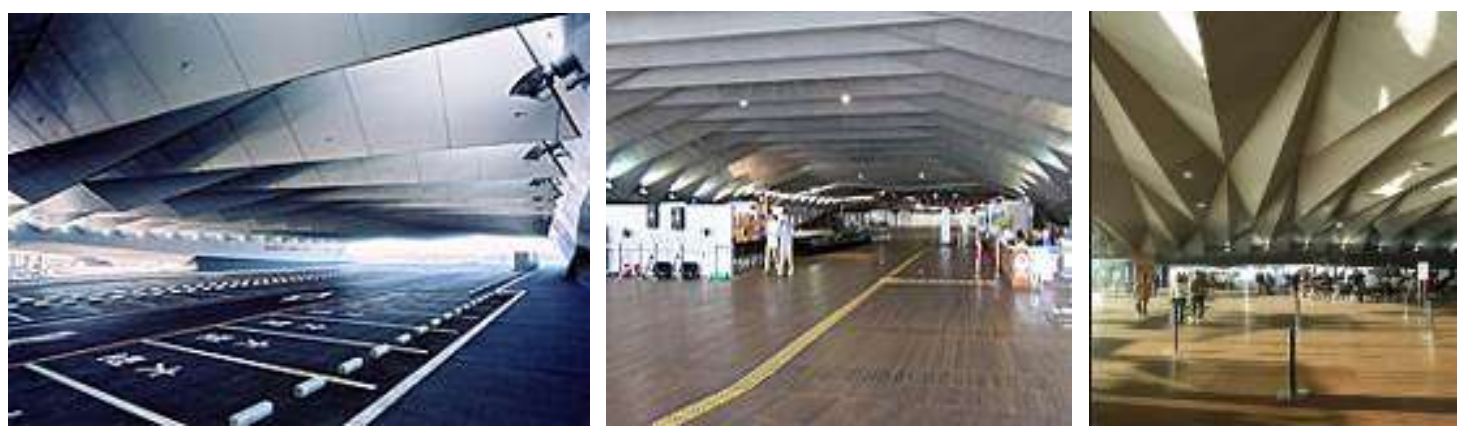

Gambar 22 : Area parkir (kiri) dan lobby (tengah dan kanan) Terminal Penumpang Osanbashi Hall Sumber : www.osanbashi.com, diunduh 14 Juni 2013

Hampir seluruh bentuk sirkulasi pada Terminal Penumpang di Osanbashi Hall terbuka di satu sisi seperti lobby, lounge dan anjungan. Sirkulasi terbuka di satu sisi pada lobby terdapat pada sirkulasi toko-toko dan restoran sebagai ruang yang harus dilewati di lobby. Sedangkan sirkulasi terbuka di satu sisi pada Longue diarahkan dengan material kaca sebagai pemisah antara longue dan dek kapal.
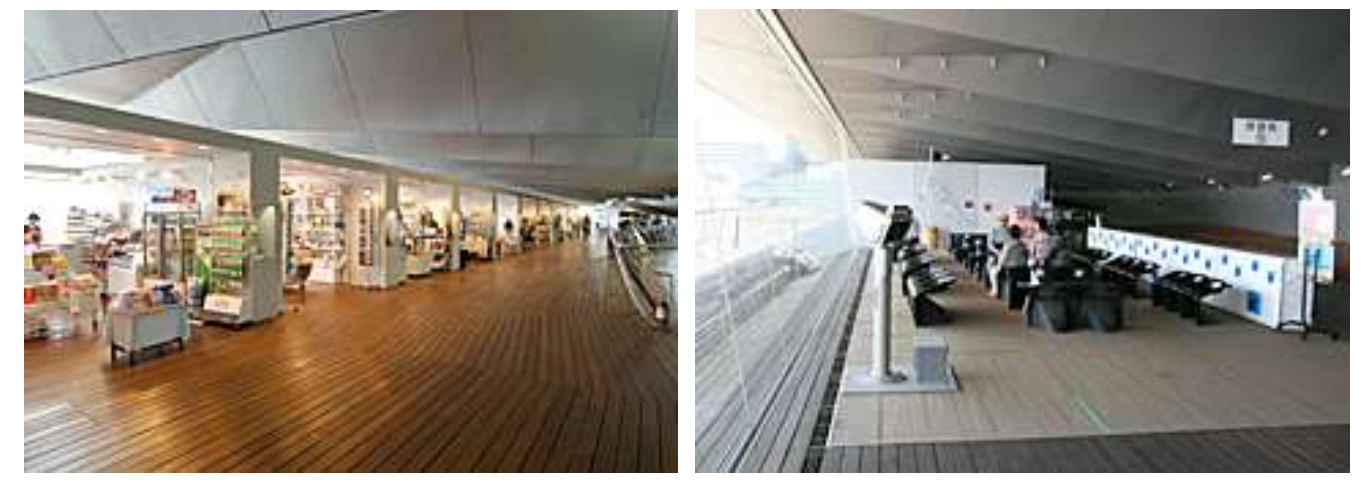

Gambar 23 : Toko dan restoran (kiri) dan lounge (kanan) Terminal Penumpang Osanbashi Hall Sumber : www.osanbashi.com, diunduh 14 Juni 2013

Sementara itu, sirkulasi terbuka di satu sisi pada plaza lantai atap memberikan kontinuitas visual dan kontinuitas ruang dengan ruang-ruang yang dihubungkannya karena ruang ini merupakan area untuk pengantar penumpang.
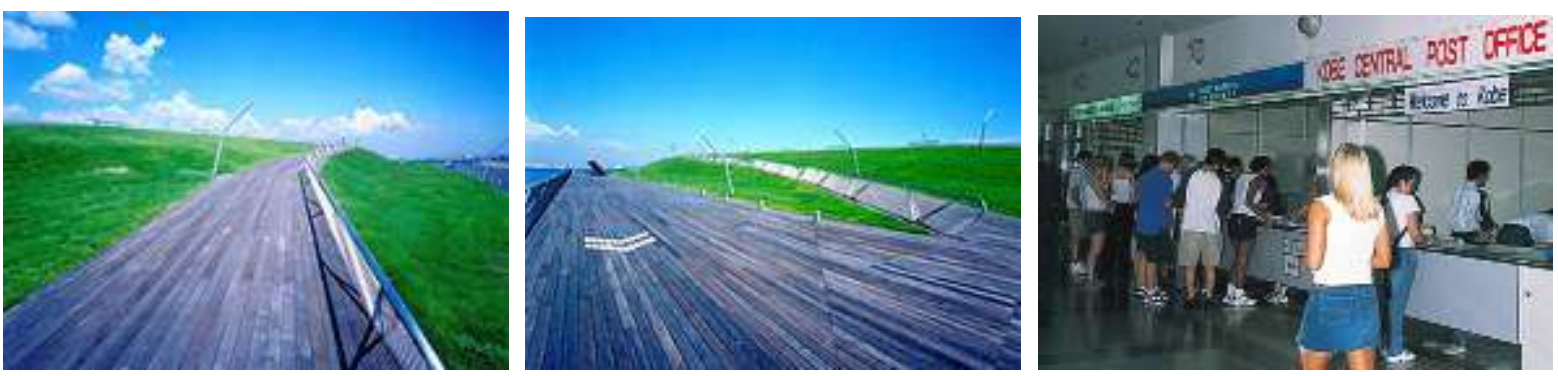

Gambar 24 : Plaza lantai atap (kiri), dek pengunjung (tengah) dan pusat informasi turis dan money exchange (kanan) pada Terminal Penumpang Osanbashi Hall

Sumber : www.osanbashi.com, diunduh 14 Juni 2013 
Sementara itu, bentuk sirkulasi tertutup kedua sisi pada Terminal Penumpang Osanbashi Hall terdapat pada jalur masuk dari area parkir ke lobby lantai 1, lobby, fasilitas CIQ dan plaza lantai atap. Sirkulasi tertutup di kedua sisi pada lobby dan jalur masuk ini sangat mendukung fungsi lobby sebagai ruangan yang difugsikan sebagai ruang untuk menampung berbagai acara kegiatan.
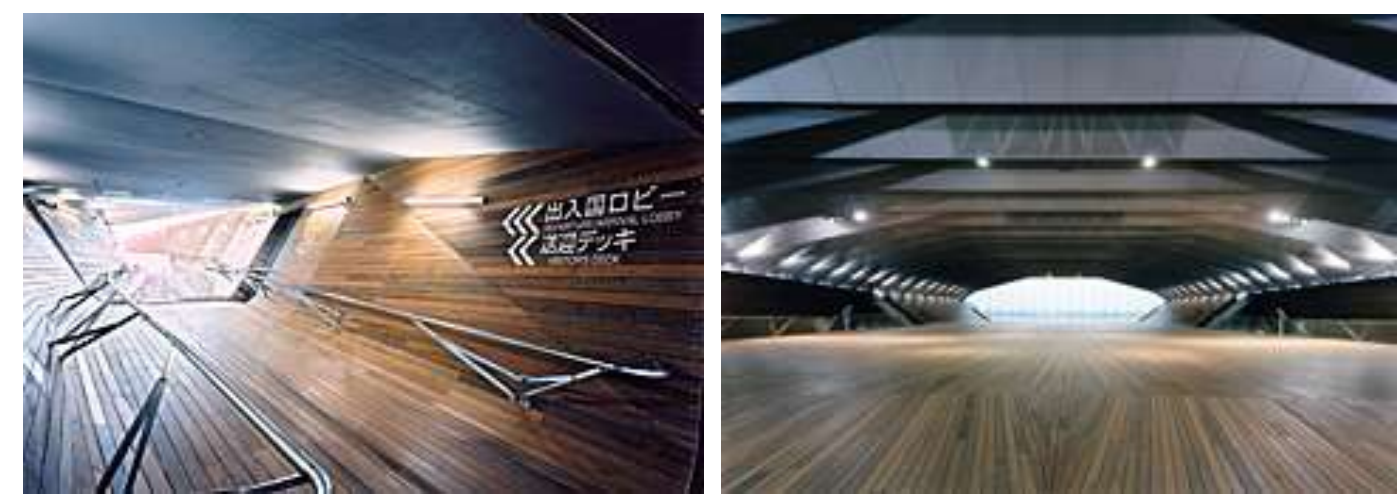

Gambar 25 : Ramp (kiri) dan hall (kanan) pada Terminal Penumpang Osanbashi Hall Sumber : www.osanbashi.com, diunduh 14 Juni 2013

Pada Terminal Penumpang Osan- bashi Hall hanya terdapat 2 (dua) buah ruang dengan bentuk sirkulasi tertutup di kedua sisi yaitu fasilitas CIQ dan sirkulasi menuju ruang Plaza lantai atap. Sirkulasi tertutup ini membuat rasa aman yang cukup tinggi pada fasilitas BCQ. Sementara pada sirkulasi ruang plaza, sirkulasi tertutup menimbulkan kesan privasi ketika menuju ruang yang diperuntukkan juga untuk kegiatan konser mini dan lainnya.
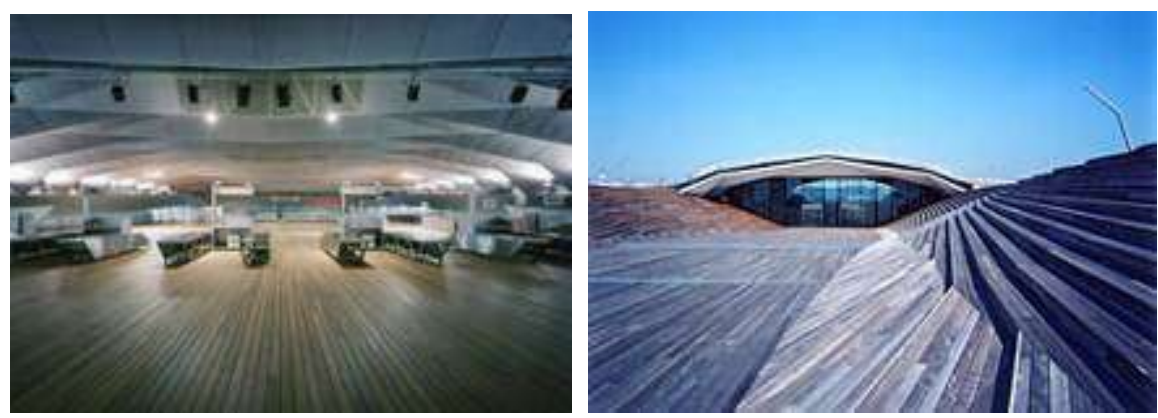

Gambar 26 : Fasilitas CIQ (Bea cukai, imigrasi dan karantina) (kiri) dan plaza acara terbuka (kanan) pada Terminal Penumpang Osanbashi Hall

Sumber : www.osanbashi.com, diunduh 14 Juni 2013

Sementara itu bentuk sirkulasi tertutup di kedua sisi terdapat pada hampir seluruh bagian dari Terminal Penumpang Internasional Kobe. Bentuk ruang sirkulasi tertutup yang terdapat pada lobby lantai 1 memberi ruang pada galeri yang berkaitan dengan ruang-ruang yang dihubungan melalui pintu-pintu masuk pada bidang dinding.

Sirkulasi tertutup berbentuk galeri koridor pada seluruh lobby memberikan kesan privasi yang cukup kuat hanya bagi pengunjung terminal yang datang maupun yang akan bepergian (Gambar 27).

Bentuk sirkulasi tertutup juga terdapat pada area pengurusan bea cukai, imigrasi, karantina dan boarding bridge. Ini memberikan rasa aman yang cukup tinggi (Gambar 28 dan Gambar 29).

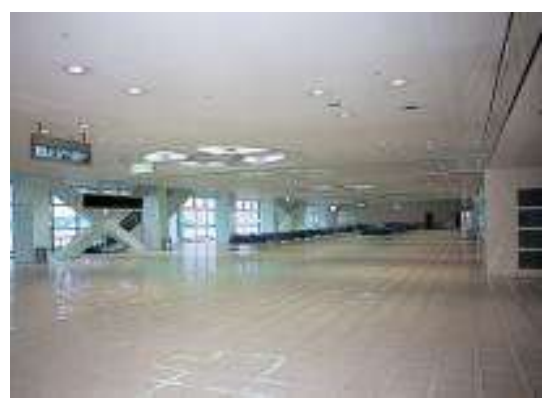

(a)

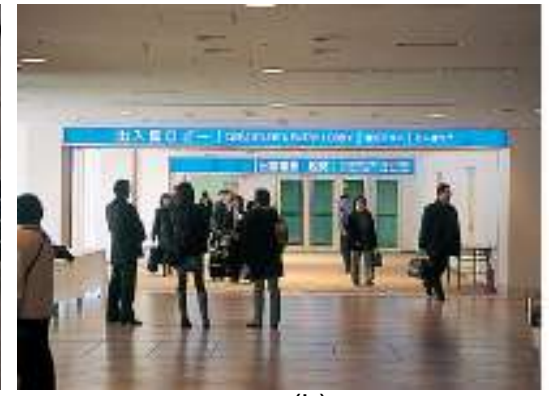

(b) 


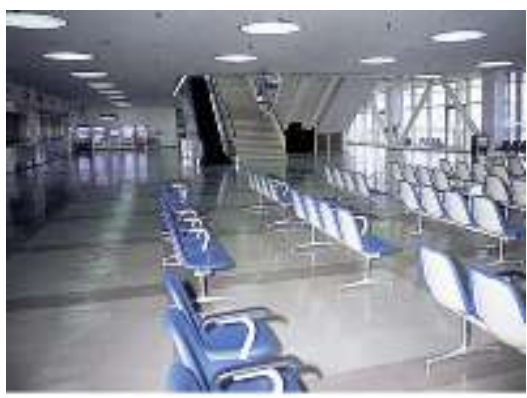

(c)

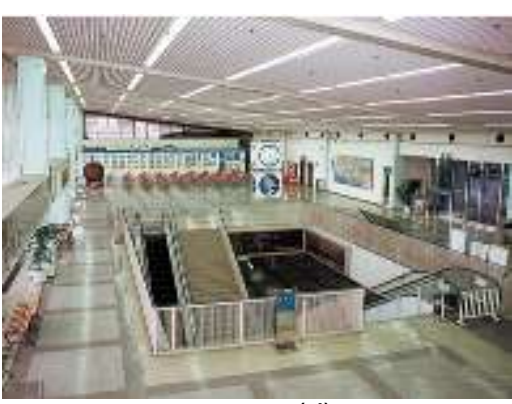

(d)

Gambar 27 : Lobby pada Terminal Penumpang Internasional Kobe berupa (a) lobby lantai 1, (b) lobby keberangkatan, (c) lobby lantai 2, (d) lobby lantai 3

Sumber : www.kobe-meriken.or.jp, diunduh 16 Juni 2013
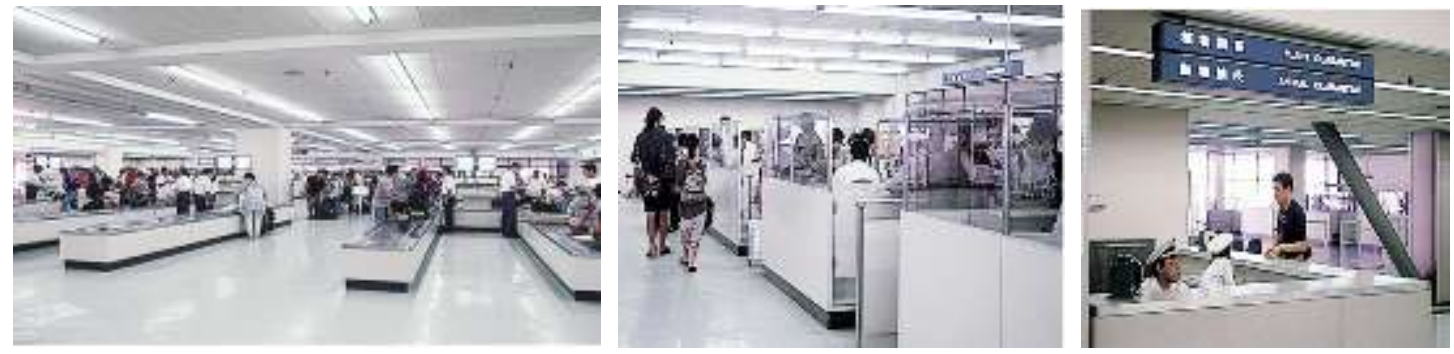

Gambar 28 : Area pengurusan bea cukai (kiri), area pengurusan imigrasi (tengah) dan area pengurusan karantina (kanan) pada Terminal Penumpang Internasional Kobe

Sumber : www.kobe-meriken.or.jp, diunduh 16 Juni 2013

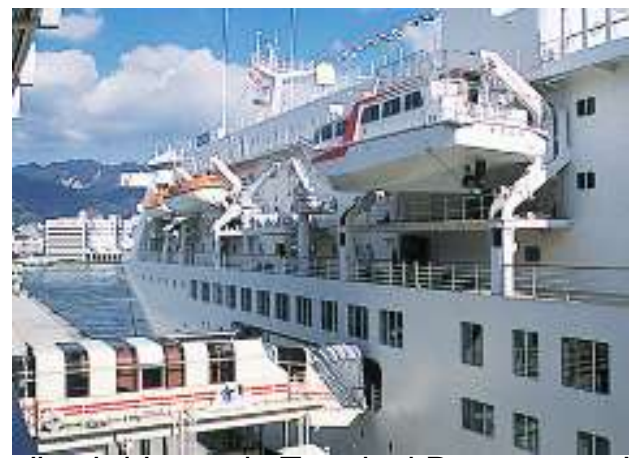

Gambar 29 : Boarding bridge pada Terminal Penumpang Internasional Kobe Sumber : www.kobe-meriken.or.jp, diunduh 16 Juni 2013

\section{Penutup}

Berdasarkan analisis yang telah dilakukan, maka dapat diambil kesimpulan yaitu:

- Fungsi terminal penumpang kapal laut adalah sebagai tempat mewadahi kegiatan pelayanan bagi penumpang kapal laut. Namun terminal penumpang kapal laut juga dapat difungsikan juga sebagai tempat untuk mewadahi kegiatan lain seperti acara atau pertunjukan dalam skala kecil yang dapat digunakan oleh publik pengantar maupun penikmat panorama pelabuhan.

- Bayaknya aktivitas yang terdapat dalam terminal penumpang kapal laut mulai dari kegiatan utama hingga kegiatan penunjang bagi masyarakat sekitar menjadikan sirkulasi menjadi masalah utama dalam perancangan.

- Sirkulasi yang digunakan dalam merancang terminal penumpang kapal laut harus memberikan kemudahan dan kenyamanan bagi seluruh penggunanya. Hal yang harus dipertimbangkan dalam merancang sirkulasi terminal penumpang kapal laut adalah sirkulasi penumpang, pengantar dan barang.

- Pencapaian ke bangunan, pintu masuk, pola sirkulasi, jalur sirkulasi dan bentuk ruang sirkulasi adalah unsur-unsur penting yang harus direncanakan dengan tepat agar sirkulasi yang digunakan dapat memberikan kemudahan dan kenyamanan bagi penggunanya.

- Unsur-unsur sirkulasi tersebut memiliki karakteristik yang berbeda pada setiap terminal penumpang yang sangat bergantung dari lokasi serta fungsi tambahan dari terminal penumpang itu sendiri.

- Pencapaian bangunan ditentukan oleh akses jalan di sekitar bangunan, sehingga pencapaiannya mengikuti akses jalan yang ada di sekitarnya. 
Sebagai fasilitas antar moda transportasi, terminal penumpang dapat berhubungan langsung dengan jalur transportasi moda lain di sekitarnya.

- Terminal penumpang kapal laut merupakan bangunan umum sebagai penyebar akses dan seterusnya perlu pencapaian langsung

- Pintu masuk ke bangunan yang menjorok ke dalam memberikan keuntungan berupa perlindungan dan menerima sebagian ruang eksterior menjadi bagian dalam bangunan sehingga tidak diperlukan suatu lahan yang luas hanya untuk fungsi pintu masuk.

- Pola sirkulasi antar ruang yang umumnya digunakan pada kedua contoh kasus yaitu pola sirkulasi linier dan pola sirkulasi radial. Pola sirkulasi radial umumnya digunakan pada ruang-ruang berkumpul seperti lobby dan hall. Sedangkan pola linier digunakan pada ruang-ruang yang ingin mengarahkan pengunjungnya untuk menuju ke suatu tempat tertentu.

- Hubungan jalur sirkulasi ruang yang digunakan dari kedua contoh kasus memiliki beberapa perbedaan. ini dikarenakan konsep penyusunan ruang yang berbeda dari masing-masing bangunan akibat dari fungsi dan lokasi yang berbeda.. Tetapi secara keseluruhan ketiga tipe hubungan jalur sirkulasi dapat digunakan dalam perancangan terminal penumpang kapal laut. Jalur sirkulasi berakhir pada ruang dimaksudkan untuk mengumpulkan misalnya pada ruang lobby. Jalur sirkulasi melewati ruang diterapkan pada ruang-ruang yang membutuhkan privasi tinggi. Sedangkan jalur sirkulasi menembus ruang dimaksudkan untuk mengarahkan pengunjung melewati ruang-ruang yang ditembusnya seperti area komersial.
- Bentuk sirkulasi tertutup diutamakan bagi ruang-ruang yang membutuhkan privasi tinggi. Bentuk sirkulasi terbuka di satu sisi untuk memberikan keamanan juga memberi arahan untuk mengantri. Sedangkan bentuk sirkulasi terbuka ditempatkan pada ruang-ruang yang bersifat publik.

\section{Daftar Pustaka}

1996. Peraturan Pemerintah RI No. 70 Tahun 1996 tentang Kepelabuhan, Departemen Perhubungan Rl

Alucci, Marcia Peinando; Leonardo Marques Monteiro. 2009. Thermal Comfort Index for The Assessment of Outdoor Urban Spaces in Subtropical Climates. University of Sao Paulo. Sao Paulo

Andiani, Dita. 2011. Terminal Feri Domestik Sekupang - Batam (Arsitektur Simbolis). Laporan Perancangan Tugas Akhir Departemen Arsitektur, Universitas Sumatera Utara. Diunduh dari http://repository.usu.ac.id/ handle/123456789/26972

Ching, Francis D. K. 2000. Arsitektur Bentuk, Ruang, dan Tatanan; edisi kedua. Erlangga. Jakarta

Cyril, Haris 1975. Dictionary of Architecture And Construction. McGraw-Hill Professional. New York.

Haronjeff, Robert. 1993. Perencanaan dan Perancangan Bandar Udara. Erlangga. Jakarta

Morlok, Edward K. 1991. Pengantar Teknik dan Perencanaan Transportasi. Erlangga. Jakarta

Triatmodjo, Bambang. 2008. Pelabuhan. Beta Offset. Yogyakarta

www.kobe-meriken.or.jp. Akses: 2013

www.osanbashi.com. Akses: 2013

www.investor.co.id. Akses: 2013 